\title{
Assessment of Pregnant Women Preference of Midwives Gender for Birth Attendant and Associated Factors :- A Faclitiy Based Cross Sectional Study, Ambo Town, Ethiopia
}

\author{
Rebuma Muleta Gutema ${ }^{1 *}$, Bazie Mekonnen ${ }^{2}$ and Addishiwet Fentahun ${ }^{2}$ \\ ${ }^{1}$ Department of Midwifery, College of Medicine and Health Sciences, Ambo University, Ambo, Ethiopia \\ ${ }^{2}$ Department of Nursing and Midwifery, College of Health Science, Addis Ababa University, Addis Ababa, \\ Ethiopia
}

*Corresponding author: Rebuma Muleta Gutema, Department of Midwifery, College of Medicine and Health Sciences, Ambo University, Ambo, Ethiopia

\begin{abstract}
Background: Worldwide, in a minute, a minimum, one woman dies from problem related to pregnancy and delivery. These problems escalate in developing countries as there is poor and less utilization of obstetrics care service in developing countries. Recognizing women's outlooks, desires, needs and worries enable the midwives to work toward a common objective of a safe and good childbirth practice. The objective of this study is therefore to identify pregnant women's preference of midwives gender for birth attendant and its associated factors in Ambo town, West shoa zone, Oromia region, Ethiopia.
\end{abstract}

Methods: A cross-sectional study was carried outamong 388 pregnant women attending antenatal care at public health facilities in Ambo town, west shoa zone, Ethiopia, from March 1 to April 1, 2018 .The data were collected through face-to-face interviews by a structured questionnaire. Descriptive analysis were performed using frequencies, percentages and binary logistic regression.

Results: Among the 388 participants, 161(41.5\%) were preferred a female midwives, $135(34.8 \%)$ had no preference/both and $92(23.7 \%)$ were preferred a male midwife. Factors associated with female gender preference of pregnant women were: religion $(\mathrm{AOR}=5.78,95 \% \mathrm{Cl}$ : $1.29,25.77$ ), Women's who have no formal education (AOR $=4.00,95 \% \mathrm{Cl}: 1.47,10.85)$, being housewife in mothers occupational status (AOR $=6.39,95 \%, \mathrm{Cl}: 2.73,14.99)$, Governmental employed $(\mathrm{AOR}=2.9,95 \%, \mathrm{Cl}: 1.15,7.32)$ and being farmer inhusbands occupation $(A O R=3.60,95 \%$ Cl: 1.23, 10.51)

Conclusion: A substantial proportion of women preferred a female midwife; a quarter preferred a male midwife and the rest had no preference. With this result, it is possible to meet the women's preference for those who have a specific preference.

\section{Keywords}

Gender, Midwife, Pregnant women, Preference

\section{Abbreviations}

ANC: Antenatal Care; AOR: Adjusted Odds Ratio; Cl: Confidence Interval; ETB: Ethiopian Birr; $\mathrm{MCH}$ : Maternal and Child Health; SVD: Spontaneous Vaginal Delivery

\section{Introduction}

Gender preference is the degree to which a woman prefers to like the same-gender or other-gender to be attended during child birth. Human resources are the most important assets of any health system. For health care systems to provide services effectively and efficiently, a well-trained, motivated personnel with well-functioning health workforce are necessary [1]. Women'sfirst choice for type of maternity caregiver have gained significance and have been recognized in studies conducted from different countries [2,3]. In the women's health arena, studies from developed countries have shown that female patients prefer female birth attendants than male, and that a female communication style is different from that of a male, which partially explains higher patient satisfaction balance for female care providers [4]. Understanding patients' requirements on the part of the health

Citation: Gutema RM, Mekonnen B, Fentahun A (2021) Assessment of Pregnant Women Preference of Midwives Gender for Birth Attendant and Associated Factors :- A Faclitiy Based Cross Sectional Study, Ambo Town, Ethiopia. Int J Womens Health Wellness 7:134. doi.org/10.23937/2474-1353/1510134 Accepted: December 29, 2021: Published: December 31, 2021

Copyright: (C) 2021 Gutema RM, et al. This is an open-access article distributed under the terms of the Creative Commons Attribution License, which permits unrestricted use, distribution, and reproduction in any medium, provided the original author and source are credited. 
care might help to increase the number of women in seeking skilled birth attendant. A study conducted in Israel showed that around $87 \%$ of the participants preferred female obstetricians [5-7]. Women felt that they would be uncomfortable if procedures that involves the genital area to be conducted by male midwives like vaginal examination, catheterization and childbirth [8]. The other reasons for the preference of female caregivers were personal characteristics such as women's/patient's lack of ability to communicate with health care providers, low health literacy, lack of income and reliance are being the most important parameter among the respondents [9-11]. The role of obstetrics care services in reducing maternal morbidity and mortality has got significant recognition, though implementing and providing effective maternity care for women in developing country need an effort. Majority of the African countries including Ethiopia are providing free health care services for delivery care to alleviate this problem and attain the sustainable development goal [12]. Midwives are the frontline care givers and supporter for maternal and infants at the most susceptible time in their lives. Midwives provide almost $87 \%$ of all basic sexual and reproductive as well as maternal and neonatal health care services [13]. However, most women do not have equal access to the services, as there is low delivery in health facility and low skilled birth attendant. According to data from EDHS (Ethiopian demographic health survey) 2016, birth attended by skilled birth attendant in Ethiopia is nearly 28 percent and health facility delivery is $26 \%[14,15]$. Majority of pregnant women in the study area and the country do not give birth in a health institution by skilled birth attendant. As a result, every year many women die from complications related to pregnancy and child birth. The purpose of providing basic maternity care is to preserve the life and wellbeing of the mothers with due attention to alleviate the health threat through increasing the proportion of birth attended by skilled birth attendants [16]. As a study conducted in Bahir Dar town on disrespect and abuse of women during child birth indicate $67.1 \%$ of women encounter disrespect and mistreatment during child birth [17]. Sufficient care throughout pregnancy and delivery are important based on the women's choice or preference. Therefore identification of women's preference for birth attendant and factors associated with the strong design will be an input for policy maker to design appropriate intervention method to increase institutional delivery.

\section{Methods}

A facility based cross-sectional study was carried out among pregnant women at public health institution in Ambo town from March 1 to April 1, 2018. Ambo town is the capital city ofwest shoa zone, Oromia regional state and located at 114 kilometers to the west of Addis Ababa the capital city of Ethiopia. There are 4 governmental health institutions in Ambo town that are providing maternal health care services. These include: Ambo University referral hospital, Ambo general hospital, Awaro health center and Ambo health center. In our study, Ambo general hospital, Awaro health center and Ambo health center who are providing ANC and delivery services at the study time were selected. Ambo University referral hospital was not providing ANC service during the study time and excluded. According to the 2019 population estimation, the total residents of Ambo town was estimated to be 80,712 . The study population were all sampled pregnant women who visit the selected health facilities in the town.

\section{Sample size and sampling procedure}

The required sample size was calculated based on single population proportions formula by the assumptions of $p=54.7 \%$ is preference obtained from women preference on the place of delivery and birth attendant in shashemene town [18], 95\% confidence level, $5 \%$ desired degree of accuracy. By addinga $10 \%$ non-response rate, the final calculated sample size was found to be 401 . The calculated Sample size was allocated to each health institutions by proportional allocation formula. By taking the last three months report which is 857 antenatal care attendants as a sample frame $(\mathrm{N})$, the study unit is selected by systematic sampling technique. The first study participant was selected by lottery method based on their ANC registration number and then every $k^{\text {th }}$ value $(k=N / n=857 / 401=2$, where $N$ is sample frame, $\mathrm{n}$ is sample size for this study and $\mathrm{k}$ is regular interval between study participants).

\section{Data collection tools, procedure, and quality control}

The questionnaire was initially prepared in English version by reviewing different related literature $[5,13,14,19,20]$ and translated to Afan Oromo, an area language and then translated back to English by language experts to maintain the consistency. The questionnaire includes socio-demographic characteristics, past obstetric history, and gender preference. Data was collected from pregnant women through face to face interviewing by using structured pretested questionnaire. The data collection was carried out by 6 trained degree holders' health care providers and supervised by 2 MSc holders. Data quality was controlled during data collection, coding, entry, and analysis process. Two-days training were given for the data collectors. The collected data were reviewed and checked for consistency, clarity; completeness and accuracy throughout the data collection process.

\section{Operational definitions}

- Gender: Socially created attributes assigned to males and females result in differences in status and roles. 
- Gender preference: The pregnant women, who had attended labor and delivery wards and choose female, male, or either sex of midwife for birth attendant.

- Birth attendant: A health personnel who attend the midwifery courses and able to conduct child birth.

\section{Data processing and analysis}

The collected data was entered in to Epi data version 3.3.1 software after coded and checked the completeness and exported to statistical package for social science SPSS version 20 for analysis. Descriptive analysis using frequencies, means, percentage and standard deviations were done and presented in the form of text and tables. Binary Logistic regression was used to see the association between gender preference and the explanatory variables which had P-value less than 0.25 . The model goodness of fit was tested by using Hosmer-Lemeshow. Finally strength of association was weighed using odds ratio at $95 \%$ confidence interval and $\mathrm{P}$-value $<0.05$.

\section{Results}

\section{Socio-demographic characteristics of the respon- dents}

A total of 388 pregnant women attending antenatal clinic participated in the study resulting the response rate of $97 \%$. The mean age of the respondents was 29 years with $S D \pm 6.89$ years. Among the participants 311 (74.6\%) were married and $343(88.4 \%)$ pregnant women residence were in urban. Regarding their religion 247 (63.7\%) pregnant women were followers of protestant religion. More than quarter (35.1\%) of pregnant women'soccupation was house wife. Related to the educational status, 138 (35.6\%) of the study participants had attended secondary school and concerning their monthly income 103 (26.5\%) of the study participants earn less than 1000 Ethiopian birr/31\$ (Table 1).

\section{Women's past obstetric history and care}

One hundred fifty one $(38.9 \%)$ of the study participants were nulliparous and only $5.7 \%$ of them said that their pregnancy was unplanned. Regarding the mode of delivery majority (93.6\%) of the women gave their previous delivery by spontaneous vaginal birth and 9(3.7\%) women have delivered by caesarean section. From 237 respondents who have history of previous delivery, 108(45.5\%) participants have reported that their previous delivery was attended by a female care provider, $81(34.1 \%)$ of them have been attended by a male midwives and 39 (16.4\%) were attended by both/ either gender of the midwives. Related to pregnancy problem or complication, $230(97 \%)$ to the women gave birth without complication and $7(2.6 \%)$ were deliver with complication (Table 2).
Table 1: Socio-demographic characteristics of pregnant women at health facilities in Ambo town, March-April, 2018 (n $=388$ ).

\begin{tabular}{|c|c|c|c|}
\hline \multicolumn{2}{|l|}{ Variables } & \multirow{2}{*}{\begin{tabular}{|l} 
Frequency \\
125
\end{tabular}} & \multirow{2}{*}{\begin{tabular}{|l|}
$(\%)$ \\
32.2
\end{tabular}} \\
\hline \multirow{4}{*}{$\begin{array}{l}\text { Respondents } \\
\text { Age (years) }\end{array}$} & $<=21$ & & \\
\hline & $22-24$ & 90 & 23.2 \\
\hline & $25-27$ & 88 & 22.7 \\
\hline & $28+$ & 85 & 21.9 \\
\hline \multirow[t]{3}{*}{ Marital Status } & Married & 358 & 92.3 \\
\hline & Single & 24 & 6.2 \\
\hline & Divorced & 6 & 1.5 \\
\hline \multirow[t]{3}{*}{ Ethnicity } & Oromo & 347 & 89.4 \\
\hline & Gurage & 8 & 2.1 \\
\hline & Amhara & 33 & 8.5 \\
\hline \multirow[t]{3}{*}{ Religion } & Protestant & 247 & 63.7 \\
\hline & Muslim & 22 & 5.7 \\
\hline & Orthodox & 119 & 30.7 \\
\hline \multirow{4}{*}{$\begin{array}{l}\text { Woman } \\
\text { Educational } \\
\text { Status }\end{array}$} & $\begin{array}{l}\text { No formal } \\
\text { education }\end{array}$ & 71 & 18.3 \\
\hline & $\begin{array}{l}\text { Primary } \\
\text { education }\end{array}$ & 101 & 26.0 \\
\hline & $\begin{array}{l}\text { Secondary } \\
\text { education }\end{array}$ & 138 & 35.6 \\
\hline & $\begin{array}{l}\text { Diploma and } \\
\text { above }\end{array}$ & 78 & 20.1 \\
\hline \multirow{4}{*}{$\begin{array}{l}\text { Husbands } \\
\text { educational } \\
\text { status }\end{array}$} & $\begin{array}{l}\text { No formal } \\
\text { education }\end{array}$ & 52 & 13.4 \\
\hline & $\begin{array}{l}\text { Primary } \\
\text { education }\end{array}$ & 78 & 20.1 \\
\hline & $\begin{array}{l}\text { Secondary } \\
\text { education }\end{array}$ & 154 & 39.7 \\
\hline & $\begin{array}{l}\text { Diploma and } \\
\text { above }\end{array}$ & 104 & 26.8 \\
\hline \multirow{4}{*}{$\begin{array}{l}\text { Woman's } \\
\text { occupation }\end{array}$} & House wife & 136 & 35.1 \\
\hline & $\begin{array}{l}\text { Governmental } \\
\text { employee }\end{array}$ & 101 & 26.0 \\
\hline & $\begin{array}{l}\text { Private } \\
\text { employee }\end{array}$ & 62 & 16.0 \\
\hline & Merchant & 89 & 22.9 \\
\hline \multirow[t]{5}{*}{$\begin{array}{l}\text { Husband's } \\
\text { occupation }\end{array}$} & $\begin{array}{l}\text { Governmental } \\
\text { employee }\end{array}$ & 82 & 21.1 \\
\hline & Merchant & 113 & 29.1 \\
\hline & Farmer & 49 & 12.6 \\
\hline & Daily labor & 46 & 11.9 \\
\hline & $\begin{array}{l}\text { Private } \\
\text { employee }\end{array}$ & 98 & 25.3 \\
\hline \multirow[t]{4}{*}{ Economic status } & $<=1000.00$ & 103 & 26.5 \\
\hline & $\begin{array}{l}1001.00- \\
2000.00\end{array}$ & 121 & 31.2 \\
\hline & $\begin{array}{l}2001.00- \\
3000.00\end{array}$ & 83 & 21.4 \\
\hline & $3001.00+$ & 81 & 20.9 \\
\hline \multirow[t]{2}{*}{ Residence } & Urban & 343 & 88.4 \\
\hline & Rural & 45 & 11.6 \\
\hline
\end{tabular}


Table 2: Past obstetric history of pregnant women at Ambo town, March-April, $2018(n=388)$.

\begin{tabular}{|c|c|c|}
\hline Variables & Frequency & $(\%)$ \\
\hline \multicolumn{3}{|l|}{ Status of pregnancy } \\
\hline planned & 366 & 94.3 \\
\hline Unplanned & 22 & 5.7 \\
\hline \multicolumn{3}{|l|}{ Parity } \\
\hline Nulliparous & 151 & 38.9 \\
\hline $1-2$ & 201 & 51.8 \\
\hline$\geq 3$ & 36 & 9.3 \\
\hline \multicolumn{3}{|l|}{ Mode of delivery } \\
\hline 1.Spontaneous vaginal Delivery & 222 & 93.6 \\
\hline 2. Caesarian section & 9 & 3.7 \\
\hline 3. Assisted delivery(vacuum) & 6 & 2.5 \\
\hline \multicolumn{3}{|l|}{ Delivery outcome } \\
\hline No complication & 230 & 97.04 \\
\hline With complication & 7 & 2.6 \\
\hline \multicolumn{3}{|l|}{ ANC Visit } \\
\hline Yes & 207 & 87.3 \\
\hline No & 30 & 12.6 \\
\hline \multicolumn{3}{|l|}{ Previous delivery attendant } \\
\hline Female & 108 & 45.5 \\
\hline Male & 81 & 34.1 \\
\hline Both & 39 & 16.4 \\
\hline \multicolumn{3}{|l|}{$\begin{array}{l}\text { In your opinion, what are some } \\
\text { things a pregnant woman can } \\
\text { do to prepare for birth? }\end{array}$} \\
\hline Preferred birth attendant & 49 & 12.6 \\
\hline Desired place of birth & 97 & 25.0 \\
\hline Birth companion & 65 & 16.8 \\
\hline $\begin{array}{l}\text { Funds for birth-related and } \\
\text { emergency expenses. }\end{array}$ & 151 & 38.9 \\
\hline Others ${ }^{* *}$ & 26 & 6.7 \\
\hline
\end{tabular}

**: Porridge, cloth, etc.

\section{Preference of the study participants on midwives gender}

On preference of midwives gender, $161(41.5 \%)$ women preferred a female midwife, $135(34.8 \%)$ of the women had no preference (or no matter if both) and $92(23.7 \%)$ preferred a male midwife. On reason of gender preference, from the respondents who have preferred malemidwives, $70(76.9 \%)$ of them said that males are more empathetic than females, while from those who prefer female; 91(56.17\%) said that females are more empathetic than males, $31(19.13 \%)$ said they are ashamed (fear) of male midwives, $19(11.7 \%)$ said females are culturally accepted. On encouragement to be a midwife $305(78.6 \%), 62(16.0), 21(5.4 \%)$ reported that both of them, female and male should be encouraged to be a midwife respectively (Table 3 ).
Table 3: Pregnant women preference of midwives gender for delivery service at health facilities in Ambo town, March-April, $2018(n=388)$.

\begin{tabular}{|c|c|c|}
\hline Variables & Frequency & (\%) \\
\hline \multicolumn{3}{|l|}{$\begin{array}{l}\text { Preferred midwife gender for } \\
\text { delivery attendant }\end{array}$} \\
\hline Female & 161 & 41.5 \\
\hline Male & 92 & 23.7 \\
\hline No preference/both & 135 & 34.8 \\
\hline \multicolumn{3}{|l|}{$\begin{array}{l}\text { Why do you prefer male } \\
\text { midwives? (For Who prefer males) }\end{array}$} \\
\hline $\begin{array}{l}\text { Males communicate more than } \\
\text { female }\end{array}$ & 10 & 10.9 \\
\hline Males are empathetic than female & 70 & 76.9 \\
\hline Male midwife is more skill full & 11 & 12.09 \\
\hline \multicolumn{3}{|l|}{$\begin{array}{l}\text { Why do you prefer female } \\
\text { midwives? (For Who prefer } \\
\text { females) }\end{array}$} \\
\hline Females are empathetic & 91 & 56.17 \\
\hline $\begin{array}{l}\text { Female midwife is more skill full } \\
\text { than Male }\end{array}$ & 12 & 7.4 \\
\hline $\begin{array}{l}\text { Females are culturally accepted as } \\
\text { midwives }\end{array}$ & 19 & 11.7 \\
\hline Shame of male & 31 & 19.13 \\
\hline Religion & 9 & 5.5 \\
\hline \multicolumn{3}{|l|}{$\begin{array}{l}\text { Will you accept to be examined } \\
\text { and attended by a male midwife? }\end{array}$} \\
\hline Yes & 374 & 96.4 \\
\hline No & 4 & 1.0 \\
\hline No opinion & 10 & 2.6 \\
\hline \multicolumn{3}{|l|}{$\begin{array}{l}\text { Whom will you encourage to be a } \\
\text { midwife? }\end{array}$} \\
\hline Female & 62 & 16.0 \\
\hline Male & 21 & 5.4 \\
\hline Both & 305 & 78.6 \\
\hline \multicolumn{3}{|l|}{$\begin{array}{l}\text { How do you see a male being a } \\
\text { midwife }\end{array}$} \\
\hline Should be encouraged & 368 & 94.8 \\
\hline Don't like & 8 & 2.1 \\
\hline No opinion & 12 & 3.1 \\
\hline
\end{tabular}

\section{Factors influencing pregnant Women's gender preference for midwives birth attendants}

Religion, woman's educational status, woman's occupation and husband educational status have significant association with wome gender preference. Muslim pregnant women were nearly six times more likely prefer female midwives gender than male when compared to Protestants $(\mathrm{AOR}=5.78,95 \% \mathrm{Cl}: 1.29$, 25.77). Furthermore women who had no formal education and primary education were four times and two times more likely prefer female midwives gender than male gender when compared to women who have diploma and above respectively $(\mathrm{AOR}=4.00,95 \% \mathrm{Cl}$ : $1.47,10.86)(\mathrm{AOR}=2.48,95 \% \mathrm{Cl}: 1.00,6.18)$. Another 
Table 4: Multinomial regression analysis of factors associated with Pregnant women preference of midwives gender for delivery at health facilities in Ambo town, March-April, $2018(n=388)$.

\begin{tabular}{|c|c|c|c|c|}
\hline Category & Variables & $\mathbf{N}(\%)$ & COR(95\% CI) & AOR $(95 \% \mathrm{Cl})$ \\
\hline \multirow{20}{*}{ Female } & Religion & & & \\
\hline & Orthodox & $50(12.9)$ & $0.77(0.43,1.40)$ & $0.89(0.52,1.55)$ \\
\hline & Muslim & $19(4.9)$ & $4.53(0.96,21.32)$ & $5.78(1.29,25.77)^{*}$ \\
\hline & Protestant & $92(23.7)$ & 1 & 1 \\
\hline & Woman's educational status & & & \\
\hline & No formal education & $41(10.6)$ & $3.95(1.79,8.72)$ & $4.00(1.47,10.85)^{*}$ \\
\hline & Primary education & $44(11.3)$ & $2.38(1.15,4.93)$ & $2.48(1.00,6.18)^{*}$ \\
\hline & Secondary education & $57(14.7)$ & $1.90(0.96,3.75)$ & $2.288(1.02,5.12)$ \\
\hline & Diploma and above & $19(4.9)$ & 1 & 1 \\
\hline & Woman's occupation & & & \\
\hline & Governmental employee & $35(9.0)$ & $2.70(1.15,7.32)$ & $2.90(1.15,7.32)^{*}$ \\
\hline & House wife & $84(21.6)$ & $4.94(2.30,10.57)$ & $6.39(2.73,14.99)^{*}$ \\
\hline & Merchant & $25(6.4)$ & $0.73(0.33,1.60)$ & $1.04(0.43,2.50)$ \\
\hline & Private employee & $17(4.4)$ & 1 & 1 \\
\hline & Husband's occupation & & & \\
\hline & Governmental employee & $37(9.5)$ & $1.12(0.54,2.35)$ & $1.28(0.56,2.95)$ \\
\hline & Merchant & $35(9.0)$ & $0.68(0.34,1.35)$ & $0.70(0.33,1.46)$ \\
\hline & Farmer & $31(8.0)$ & $3.31(1.20,9.07)$ & $3.60(1.23,10.51)^{*}$ \\
\hline & Daily labor & $19(4.9)$ & $1.74(0.63,4.73)$ & $1.75(0.61,5.01)$ \\
\hline & private employee & $39(10.1)$ & 1 & 1 \\
\hline \multirow[t]{5}{*}{ Either/both } & Woman's occupation & & & \\
\hline & House wife & $25(6.4)$ & $0.74(0.33,1.65)$ & $0.78(0.34,1.80)$ \\
\hline & Governmental employee & $35(9.0)$ & $0.90(0.42,1.93)$ & $0.95(0.40,2.24)$ \\
\hline & Merchant & $50(12.9)$ & $2.85(1.24,6.58)$ & $2.92(1.22,6.96)^{*}$ \\
\hline & Private employee & $25(6.4)$ & 1 & 1 \\
\hline
\end{tabular}

*: Male is taken as the reference category in this regression analysis.

independent variable that had significant association with gender preference were occupational status. House wives when compared to private employed were six times more likely prefer female gender for delivery service than male $(\mathrm{AOR}=6.39,95 \% \mathrm{Cl}: 2.73,14.99)$ and Governmental employed women compared to private employed were three times more likely prefer female gender than male gender $(A O R=2.91,95 \% \mathrm{Cl}: 1.15$, 7.32). Merchant pregnant women compared to private employed were three times more likely prefer both gender than male gender. On the other hand pregnant women whom their husbands are farmers compared to those who are privately employed were three times more likely prefer female than male $(A O R=3.61,95 \% \mathrm{Cl}$ : 1.24, 10.52) (Table 4).

\section{Discussion}

The findings of this study identified the women's preference on midwifes gender for delivery care service and associated factors during child birth at the health facilities.

The preference for female midwives and male midwives were $41.5 \%$ and $23.7 \%$ respectively. The female preference in this study was lower than the studies carried out in Syria (85\%), Israeli Druze women's (63.8\%) and shashemene (54.7\%) [5,8,21]. This may be due to more Muslim follower women are dominant in the above study area than our study area. Another reason for this disparity may be elucidated by the fact that the current study largely based on urban population. The urban women have a tendency to have better access to education as there is low female preference in women of higher educational level in this study. Also in this study $34.8 \%$ had no preference/no matter if male or female midwives. This result is similar with the research conducted in Turkey, Michigan and Savannah $[19,22,23]$. For example study conducted in turkey showed that nearly half of the women have given no rank for obstetrician/gynecologist gender choice when they had obstetric and gynecologic problems. Muslim women compared to protestants were six times more likely preferred female gender than male gender. This finding is comparable with study conducted on preference of birth attendants in Syria and Israel $[5,21]$. This may be because in Islamic religion, the physical covering of the body as a self and respect their religionmen and women both mandatory 
to show modesty in their dress, but women modesty in Islamic culture is more sensitive and iconic $[24,25]$. As it is commonly acknowledged that patients and their families have the right to decide the gender of their health care providers, it is the hospital's and health care providers obligation to care patients with their preferred health care provider.

In this research, Occupation and educational status of the women were found to be the most significant factor affecting gender preference. Women's who have no formal education were more likely select female midwives. This is similar with the study conducted in Israel and Turkey $[5,26]$. The preference of pregnant women for female midwife, decrease as the women's educational status increase. This means that women whom their educational level is good do not fear or ashamed with male midwives. Women who are house wives when related to private employed were six times more likely prefer female midwife than male midwife and governmental employed as compared to private employed were three times more likely prefer female midwife than male midwife. This result is in line with the studies conducted in Shashemene and Turkey $[18,26]$. As female care givers show their gender-related roles they think they do not fear each other and they are more preferred for care, which is believed as a special position for women. Another reason for female preference may be due to prevalence of disrespect and abusive care during child birth by male care providers, as manifested by study conducted on Prevalence of disrespect and abuse during facility based child birth which is (91.7\%). Despite this preference majority (61\%) of mothers choice/preference of birth attendant for child birth were not protected $[8,17]$.

Some limitations of our study: This is a cross-sectional study and may not be enough for the researcher to establish cause-effect relationship between the possible determinants of gender preference and the outcome of interest. Recall bias may happen since women who have given birth in the past may forget the gender of their birth attendants. Also the study conducted only in health facility and not generalized the community.

\section{Conclusion and Recommendation}

A large proportion of women preferred a female midwife; nearly a quarter of the participants preferred a male midwife and the rest had no preference. With this variation it should be possible to meet the women's preference for those who have a specific preference. Muslim in religion, low educational status, being house wife in mothers occupational status and being farmer in husband occupation were influenced gender preference. Maternal health promotion and information should take into account on preferences of their care provider. So, moderation measure is necessary to ensure the right and informed choice.
We recommend that, there should be a good understanding and expand services availability and accessibility at health care facility. A service of gendersensitive health care is a significant issue in the modern health care. Consideration should be given to the choice of women to confirm equal access to maternity health care services. Government and policy makers should work on approaches and Programs on the training and recruitment of midwives. Health care professions should work to improve women's health care service in order to increase maternal health care service utilization. For further research: This study has established the factors of gender preference in encouraging the training of skilled birth attendant.

\section{Declarations}

\section{Ethics approval and consent for participation}

Ethical review Committee (IRC) of Addis Ababa University approved this study. Letter of permission was soughed from West Shoa Zonal health department and from each health institution. Verbal consent was taken from the participants after the data collectors clarified the objectives of the study, processes and their right to refuse not to participate at any time. Furthermore, confidentiality of the study participants was assured.

\section{Consent for publication}

Not applicable.

\section{Availability of data and materials}

The datasets produced and/or analyzed during this study are not publicly available due to some privacy reasons but are available from the corresponding author on time of request.

\section{Competing interests}

The authors stated that they have no competing interests.

\section{Funding}

Not applicable.

\section{Authors' contributions}

RM: Formed and designed the research, control the data collection, analyze the data and develop the manuscript; BM and AF supervised the data collection, analyzed, edited the data and reviewed the manuscript. All authors read and agreeon the final manuscript.

\section{Acknowledgements}

We are great full to thank Addis Ababa University for the approval of the ethical clearance and financial support for this study.We thank data collectors, supervisors and respondents for their valuable contributions and respond. Finally, our sincere thanks also go to Mr. Dereje Bayissa and Mr.Gizachew Abdisa for their valuable comments and suggestion. 


\section{References}

1. Manyazewal T (2017) Using the World Health Organization health system building blocks through survey of healthcare professionals to determine the performance of public healthcare facilities. Arch Public Health 75: 1-8.

2. Fawsitt CG, Bourke J, Lutomski JE, Meaney S, McElroy $B$, et al. (2017) What women want: Exploring pregnant women's preferences for alternative models of maternity care. Health Policy 121: 66-74.

3. Amir H, Abokaf H, Levy YA, Azem F, Sheiner E (2018) Bedouin women's gender preferences when choosing obstetricians and gynecologists. J Immigr Minor Health 20: 51-58.

4. Janssen SM, Lagro-Janssen AL (2012) Physician's gender, communication style, patient preferences and patient satisfaction in gynecology and obstetrics: A systematic review. Patient Educ Couns 89: 221-226.

5. Amer-Alshiek J, Alshiek T, Levy YA, Azem F, Amit A, et al. (2015) Israeli Druze women's sex preferences when choosing obstetricians and gynecologists. Isr J Health Policy Res 4: 13.

6. Henderson J, Gao H, Redshaw M (2013) Experiencing maternity care: The care received and perceptions of women from different ethnic groups. BMC Pregnancy and Childbirth 13: 196.

7. Guimond ME, Salman K (2013) Modesty matters: Cultural sensitivity and cervical cancer prevention in Muslim women in the United States. Nurs Womens Health 17: 210-216.

8. Mthombeni CS, Maputle MS, Khoza LB (2018) Perceptions of postpartum mothers towards the care provided by male student midwives at labour units in Limpopo Province, South Africa. Afr J Reprod Health 22: 60-67.

9. Otolorin E, Gomez P, Currie S, Thapa K, Dao B (2015) Essential basic and emergency obstetric and newborn care: from education and training to service delivery and quality of care. Int J Gynecol Obstet 130: S46-S53.

10. McLean M, Al Yahyaei F, Al Mansoori M, Al Ameri M, Al Ahbabi S, et al. (2012) Muslim women's physician preference: Beyond obstetrics and gynecology. Health Care Women Int 33: 849-876.

11. Kenny A, Farmer J, Dickson-Swift V, Hyett N (2015) Community participation for rural health: A review of challenges. Health Expect 18: 1906-1917.

12. Union A (2016) 2016 MDGs to Agenda 2063/SDGs Transition Report - Towards an integrated and coherent approach to sustainable development in Africa.

13. Nieuwenhuijze MJ, Low LK, Korstjens I, Lagro-Janssen T (2014) The role of maternity care providers in promoting shared decision making regarding birthing positions during the second stage of labor. J Midwifery Womens Health 59: 277-285.
14. Belay A, Sendo E (2016) Factors determining choice of delivery place among women of child bearing age in Dega Damot District, North West of Ethiopia: a community based cross-sectional study. BMC Pregnancy and Childbirth 16: 1-8.

15. (2016) Ethiopia Demographic and Health survey 2016: Key indicators report. Addis Ababa, Ethiopia, and Rockville, Maryland, USA Ethiopia.

16. Roy L, Biswas TK, Chowdhury ME (2017) Emergency obstetric and newborn care signal functions in public and private facilities in Bangladesh. PLoS One 12: e0187238.

17. Wassihun B, Deribe L, Worede N, Gultie T (2018) Prevalence of disrespect and abuse of women during child birth and associated factors in Bahir Dar town, Ethiopia. Epidemiol Health 40: e2018029.

18. Junayde A, Molla M (2014) Community Based CrossSectional Study: Preferences of place of delivery and birth attendants among women of Hashemene town, Oromia regional state, 2012. Int J Technol Enhancements Emerg Engineer Res 2: 1.

19. Makam A, Saroja CSM, Edwards G (2010) Do women seeking care from obstetrician-gynaecologists prefer to see a female or a male doctor? Arch Gynecol Obstet 281: 443447.

20. Shavai F, Chinamasa E (2015) Expecting mothers' preferences of midwife gender: Implication for midwifery deployment. Int J Adv Res Manag Soc Sci 4: 169-183.

21. Bashour H, Abdulsalam A (2005) Syrian women's preferences for birth attendant and birth place. Birth 32: 2026.

22. Bal MD, Yılmaz SD, Beji NK, Uludağ S (2014) Muslim women choice for gender of obstetricians and gynecologist in Turkey. J Hum Sci 11: 64-73.

23. Mavis B, Vasilenko $P$, Schnuth R, Marshall J, Jeffs MC (2005) Female patients' preferences related to interpersonal communications, clinical competence, and gender when selecting a physician. Academic Medicine 80: 1159-1165.

24. Rashid Q (2017) Muslim men need to understand that the Quran says they should observe hijab first, not women. Independent 29.

25. Saguil A, Phelps K (2012) The spiritual assessment. American family physician $86: 546-550$.

26. Kirimlioglu N, Sayligil Ö (2016) Do patients prefer male or female physicians/counselors during family planning, pregnancy and birth process? A sample from Turkey. Osmangazi Tıp Dergisi 38: 28-37. 